\title{
Religion og konfirmasjon som «feelgood»
}

\author{
Empirisk studie av unges religiøsitet og tanker om religion og konfirma- \\ sjon, for de velger konfirmasjon. ${ }^{1}$
}

\section{Av Erling Birkedal og Espen Gilsvik}

I denne artikkelen utforsker vi 14-åringers forståelse av religion, og dennes sammenheng med valg av konfirmasjon. Vi finner at det er stor variasjon $i$ religies selvforståelse, og samtidig stor grad av ambivalens. Vi argumenterer for at de unge forstår konfirmasjon $i$ storre grad som en performativ rite som skal reflektere individets identitet og $i$ noen grad familietradisjonen. Riten fremstår for dem i mindre grad som religies markor knyttet til overgang fra barn til voksen. Vi bygger på materiale fra fokusgruppeintervju og survey-data fra tenåringer $i$ forkant av konfirmasjonsvalg. Vi finner at 14-åringene $i$ stor grad har en individualistisk tilnaerming til religion og valg av konfirmasjon. Majoriteten av 14-åringene omtaler religiøs variasjon i positive vendinger, mens de uttrykker skepsis til sterk grad av religiøs overbevisning.

Nøkkelord: Konfirmasjon, riter, ungdom, religiøsitet, religiøs individualisering, religiøs ambivalens

ERLING BirkedAl, f. 1954. Førsteamanuensis/prosjektleder, MF vitenskapelig høyskole, Oslo. E-post: erling.birkedal@mf.no

EsPEN GILSVIK, f.1980. Stipendiat, MF vitenskapelig høyskole, Oslo.E-post: espen.gilsvik@mf.no

\section{INTRODUKSJON}

Målet med denne artikkelen er å søke ny innsikt i unges forståelse av religion og religiøs selvforståelse og deres valg av konfirmasjon, og dermed deres forståelse av konfirmasjon som rite. Artikkelen bygger på data fra undersøkelsen «14-åringer og konfirmasjon ...». Data er samlet inn fra unge noen måneder før de skulle ta valget om konfirmasjon. Det skjedde i form av fokusgruppe-intervjuer og en spørreundersøkelse våren 2019, det året informantene fylte 14 år, ved skoler i Nord-Norge, Midt-Norge, Øst-Norge og Sør-Norge. Det ble også gjennomført en

1 Artikkelen er utviklet med støtte fra Den Norske Kirke - Kirkerådet.

Prismet - IKO-Forlaget 2021

Tilgjengelig på https://journals.uio.no/index.php/prismet. Publisert under CC BY-NC 4.0. 
kvantitativ pilot-undersøkelse på Østlandet januar 2019 (Birkedal og Grimsby, 2019). ${ }^{2}$

De konkrete forskningsspørsmål vi stiller i analyse av materialet, er:

- Hvilke implisitte forståelser av religion viser 14-åringene når de snakker om religion og religiøsitet?

- Hvilke religiøse selvforståelser har 14-åringer i dagens Norge, og hvordan henger dette sammen med valg av konfirmasjon?

- Hvordan er de unges implisitte forståelse av konfirmasjon?

Etter at vi kort redegiør for tidligere forskning på feltet og relevante teoretiske perspektiver, gjennomgår vi metoder i innhenting av datamateriale. Hoveddelen er en analyse og drøfting av data. I siste del drøfter vi våre funn og hvordan de unge forstår konfirmasjonen som rite.

\section{Tidligere STUdier OG TEORI}

Det er ikke gjort mye empirisk forskning i Norge på religiøsitet og 14-åringer, før de har valgt konfirmasjon. De fleste studier som har fokus på religion og religiøsitet i denne alderen, har skjedd blant dem som er i en kirkelig konfirmasjonsundervisning (Krupka og Reite (red.) 2010, Høeg 2017, Schweitzer et al 2010 og 2015). Det er to norske undersøkelser av unge uavhengig av konfirmasjon, som spesielt er relevante. Birkedal (2001) har studert endringer av gudstro i de tidlige tenårene, 13-15 år, og viser at de unge hadde en utpreget individualistisk tro, der det var viktig for dem å understreke at de «tror på sin egen måte». Denne studien viser at det vanligvis skjer en reorientering av religiøs identitet i disse tidlige tenårene. I hvilken retning endring skjer og hva som utløser endring, er imidlertid forskjellig (Birkedal 2001: 182-185, 214-218). Religiøs individualisering kommer også frem i Holmqvist (2007) sin kvantitative studie av 13-16-åringer. Flere av ungdommene finner det irrelevant å knytte seg til én sannhet, og begreper som i en vanlig faglig diskurs ville utelukke hverandre, brukes om hverandre. F.eks. sier noen at det er naturlig å være ateist og troende på en gang (Holmqvist 2007:79).

Vi tenker at et kjennetegn for tidlig ungdomsalder er å være i forhandling og konstruere sin egen identitet, en «identitetskonstruksjon». Der tidligere generasjoner erfarte at religiøs identitet i sterkere grad var noe man ble overlevert, forventes dagens unge i større grad å oppdage dette på egen hånd. Høeg tar i sin bok Ungdom og Religion utgangspunkt $i$ at ungdom er underveis og at religion dermed er noe som utprøves og utforskes (Høeg, 2017:9). Slik kan en forstå ungdom som «terskelmennesker» som befinner seg i et slags grenseland som

2 Artikkelen bruker noe av det samme empiriske materiale som er presentert i rapporten fra 2019. I den rapporten ble imidlertid ikke materialet drøftet nærmere, eller satt inn i en større teoretisk ramme. Det skjer med deler av materialet i denne artikkelen. Andre deler av materiale fra samme undersøkelse er analysert og drøftet nærmere i Grimsby og Birkedal 2020. 
utforsker landskapet de er på vei inn i (Victor Turner 1997). Vi vil i drøftingen spørre om dette også gjelder for 14-åringene vi har intervjuet.

Hvordan skal vi så forstå konfirmasjonen som rite? Van Gennep som formulerte en teori om riter for over hundre år siden, viser at overgangsriter karakteriseres av tre faser: adskillelse, terskel (limen) og integrasjon (Gennep 1999:132. Se også Danbolt og Stifoss-Hanssen 2014:205). Avhengig av hva en selv legger inn i riten, kan de perspektiver disse tre fasene anlegger, ha en viss relevans for konfirmasjonen. En kan vektlegge konfirmasjonen som en adskillelse fra det som var før, en integrasjon i noe nytt eller som en markering i en lengre endringsprosess. Ritualisering kan forstås som fremførelsen eller opptredenen av riten, slik den er beskrevet av den amerikanske riteforsker Tom Driver (1998), et perspektiv vi anvender i drøftingen. Vi forstår konfirmasjon som en rite der mennesket iscenesetter sitt eget liv, for å bli sett og bekreftet av seg selv og betydningsfulle andre, for noen også inkludert Gud. (Danbolt og Stifoss-Hanssen 2014:211-212). Vi viser også til Jone Salomonsen som har forsket på konfirmasjon som rite, og finner at de unge fremstilles $i$ «høysetet», som konge og dronning for en dag. De unge oppgir at det er talene ved bordet og håndspålegging ved alteret som verdsettes høyest blant de ulike elementene i konfirmasjonen (Salomonsen 2007:169-171 og Salomonsen 2003:142).

\section{Religionskompleksitet i individualismens tidsalder}

Et mulig uttrykk for individualisering og en trend vi ser i særlig grad blant unge i vestlige land, er den sterke økningen av ikke-religiøse eller nones (Davie 2015, Putnam and Cambell, 2010), forstått som en gruppe uten tilhørighet til organisert religion. Stolz (2016) bruker kategorien sekulær, og differensierer mellom de som er likegyldige og de som er opposisjonelle til religion og tro. Det er imidlertid ikke studier vi kjenner som gir innsikt i hvorfor sekulær ungdom opprettholder riter og tradisjon knyttet til religion (Høeg 2017:198).

Vi legger til grunn sosiolog Inger Furseths teori om Norge (og Norden) som et religionskomplekst samfunn. Hun sier at religiøsiteten endrer seg i flere uforutsigbare og motsetningsfylte prosesser på ulike nivåer parallelt (Furseth et al 2019). Videre bruker hun begrepene «Good, bad and feelgood religion» (Furseth 2019: 299) for å tydeliggiøre utviklingen av den offentlige presentasjonen av religion $i$ media de siste tiårene. Hun refererer til Storvolls undersøkelse (2007) som viser at kristendommen til tross for kontroversielle debatter, i stor grad omtales i positive vendinger og dermed kategoriseres som «good religion». Dette i motsetning til Islam som ofte konstrueres i problematiske vendinger og dermed «bad religion», særlig ut i fra et integreringsperspektiv. «Feelgood religion» knyttes til livsstilmagasiners fremstilling av en individualisert og subjektiv kristendom og spiritualitet som betoner velvære (Furseth 2019:300ff). Vi vil benytte disse begrepene for å 
forstå 14-åringenes uttalelser om religion.

For å utforske hvordan 14-åringene forstår egen og andres religiøsitet, må vi selv ha en nyansert forståelse. For å operasjonalisere religions-begrepet har vi gått til en dansk studie med fokusgruppe som metode, der sosiolog Ina Rosén fant fem ulike former for religiøs modalitet i intervjuene: 1) Tro: Oppfattes som noe personlig, privat og emosjonelt, og uttrykker kombinasjonen av informantens antakelser koblet med personlige erfaringer. 2) Religion: Religiøsitet som systematisert, organisert, dogmatisert, og fremstilles som noe institusjonelt og knyttet til kulturell arv. 3) Praksis: Ritualer og praksiser knyttet til religion, som fungerer som rammer i livet og identitetsmarkør. 4) Tradisjon: Personlige, emosjonelle eller valgte ritualer og praksiser relatert til religionen som gir mening eller er utført fordi de alltid har blitt utført og er ikke nødvendigvis koblet til teologisk innhold. 5) New Age: En hjelpende støttende praksis, knyttet til personlige erfaringer, kan være enten effektiv eller ineffektiv (Rosén bruker her begrepet «New Age» for å markere uavhengighet til institusjonalisert religion, ikke som en spesifikk trosretning.) (Rosén 2009: 88-99). Vi ser her en sammenheng mellom det Rosén omtaler som New Age og Furseths «feelgood religion». Vi finner det mest meningsfullt å bruke «feelgood religion» $\mathrm{i}$ tolkning av vårt materiale.

\section{Metode}

Materialet vi analyserer, bygger på fokusgruppe-intervju og spørreskjema blant elever i 8. trinn i ungdomsskolen, i vårsemesteret det året det fyller 14 år. Informantene skulle i løpet av samme året ta valget om ev. konfirmasjon.

Det ble først gjennomført 10 fokusgrupper med 5-6 personer i hver; totalt 57 ungdommer. Rekruttering av informanter skjedde gjennom samarbeid med lærere på utvalgte skoler. Dette var på fire skoler i Øst-, Midt- og Nord-Norge. Antall elever fra de fire skolene, fordelt på kjønn (J/G): Øst: 9J og 13G, Midt: 9J og 9G, Nord: 9J og 8G. Ingen av skolene var i storbymiljø med utbredt flerkulturelt miljø. Hovedtyngden var fra relativt store tettsted. Vi har heller ikke kunnskap om informantenes foreldre, annet enn det de selv forteller om sin oppvekst $i$ intervjuene.

Tre serier med bilder ble benyttet som inngang til samtalen, med fokus på henholdsvis 1) Religiøse bygg og ritualer. ${ }^{3}$ 2) Livssituasjoner.. ${ }^{4}$ ) Konfirmasjonstiden. ${ }^{5}$ Vi brukte ikke-standardiserte spørsmål, og strukturerte samtalen runde de tre bildeseriene. Samtalen utfoldet seg organisk, med fokus på den enkelte informants refleksjoner og erfaringer knyttet til spørsmål som for

3 Første bildeserie gav informantene mulighet til å assosiere fritt rundt de bildene de gjenkjente eller bemerket seg.

4 Den enkelte informant markerte på eget billedark de bilder som gav dem positiv energi og de som gav negativ energi

5 Den enkelte informant prioriterte inntil fem bilder som var viktig, og krysset av for valg av konfirmasjon på baksiden av id-kodet ark. 
eksempel: Hvilke religiøse eller ikke-religiøse tradisjoner kommer til uttrykk i din familie? Hva betyr det for deg å være en god venn? Hvordan forstår du det å være religiøs? Hvilke forventninger har du for fremtiden? Hva gir deg dårlig energi?

Spørreundersøkelsen ble gjennomført et par måneder senere ved de samme fire skolene som hadde fokusgrupper, og i tillegg en skole i Sør-Norge, fra relativt landlig sted. Av ca. 414 elever som ble invitert til å delta, svarte 309 (svarprosent $75 \%$ ). Her spurte vi blant annet om tanker om livet, religiøs selvforståelse, hva man forbinder med det å være kristen. Det er jevn kjønnsfordeling, med 146 gutter og 155 jenter, mens 8 personer oppgir «annet». Fordeling av elevene på de ulike landsdeler: Nord-Norge (ca. 70 elever, 46 svar / $66 \%$ ), Midt-Norge (111 elever, 76 svar / 68 \%), Øst-Norge (ca. 188 elever, 154 svar / $82 \%$ ), og Sør-Norge (ca. 45 elever, 33 svar / $73 \%$ ).

Utvalget av informantene er ikke valgt ut for å være representative for de ulike landsdeler. Med stor geografisk spredning og invitasjon til alle elever i årskullet på sin skole, legger vi til grunn at informantene i spørreundersøkelsen representerer en stor bredde for dette årskullet i Norge som helhet, med hensyn til ulike religiøse holdninger og praksis. En svakhet er at det er få elever med annen (ikke-kristen) religiøs tilknytning. De som hadde en slik tilknytning, i de aktuelle skoleklassene, har sannsynligvis i liten grad vært villige til å svare på undersøkelsen. Studiens pålitelighet og gyldighet påvirkes ikke bare av størrelse på utvalg og dets representativitet. Språk og spørsmålsformuleringer kan fortolkes ulikt av respondenter og forskere. Vi har lagt vekt på å forstå ungdommenes forutsetninger og måter å beskrive og uttrykke tanker om egen tro, blant annet ved bruk av en pilotundersøkelse med spørreskjema blant unge som var ett år eldre (Birkedal og Grimsby 2019). Ved at vi har kombinert dybden i kvalitative data med bredden i kvantitative data, mener vi at vi får relativt god innsikt.

\section{Resultater og anAlyse}

Vi presenterer først en analyse av svar fra den kvalitative undersøkelsen (fokusgrupper) og deretter data fra den kvantitative undersøkelsen (spørreskjema) ${ }^{6}$.

Vi søker forståelse for variasjon i de unge sin implisitte forståelse av religion og samtidig deres forståelse av egen religiøsitet. Vi benytter da den systematikken som er gjort av Ina Rosén om ulike modaliteter. Vi ser etter hvorvidt de forstår religion og eventuelt har en religiøsitet som a) Tro b) Religion c) Praksis d) Tradisjon og e) Feelgood religion (Roséns New Age). Når de unge uttaler seg, kan det tidvis være krevende å fange opp om de snakker om religion som et fenomen $i$ verden eller om det er egen religiøsitet de omtaler.

\footnotetext{
6 Lars Kåre Grimsby er ansvarlig for den datatekniske analyse av de kvantitative data. Forfatterne er ansvarlig for omtale og tolkning av data.
} 
Tro som noe personlig og emosjonelt

Flere av informantene uttrykker seg som om de forstår en religiøs tro som en personlig, emosjonell holdning der troens formål er at den skal være meningsfull og betydningsfull for den enkelte. Dette settes av enkelte i kontrast til religiøs praksis: «Du må ikke nødvendigvis gjøre noe [...] men at det betyr noe for deg». Vi ser flere eksempler på at informanter skiller mellom på den ene side det å ha en tro, forstått enten som personlig emosjonell tro eller en kognitiv tilslutning til trosinnholdet, og på den annen side det å være tilsluttet en religion, i disse tilfellene kristen kirke og kristen konfirmasjon. Dette skillet kommer spesielt til uttrykk når en skal omtale sin egen religiøsitet, slik en gutt fra en fokusgruppe i Nord-Norge sier det:

... budskapet er viktig ... det e nok til å si at jeg er kristen ... jeg tror på Bibelen ...

[man kan] konfirmere seg kristen selv om at man ikke tror på Gud.

14-åringene snakker i stor grad om å føle som et alternativ til å si at jeg mener eller jeg tenker, også når de snakker om religion. Religion knyttes imidlertid i liten grad til konkrete følelser. Av konkrete følelser som er fremtredende i intervjuene, er det tristhet og sinne som brukes gjentagende, og da er de knyttet til foreldre som krangler, ødeleggelser av miljø, krig, skilsmisse, ungdommer som røyker og drikker. Død og tap av naturen nevnes flere ganger, og følelser som engstelse, uro, oppgitthet og sinne knyttet til miljøet og klimakrisen kommer frem i samtlige fokusgrupper. Dette kan tolkes som det Vetlesen og Wiig (2018) kaller for økosorg, der de peker på at uro for fremtiden og tap av naturen mangler språk hos de unge. I vårt materiale ser vi tvert imot at dette er følelser de snakker åpent, godt og presist om. Flere av fokusgruppeintervjuene ble gjennomført samtidig med skolestreik for klima-aksjoner i flere norske byer (våren 2019), noe som ikke bør underkjennes som en faktor for at miljø og klima er fremtredende i materialet.

Når vi spør om hvorfor de unge tror at mennesker er religiøse eller har en tro på Gud, får vi i stor grad en psykologisk begrunnelse, om håp og trøst. Vi finner uttrykk om at man «trenger» noe å tro på og et håp knyttet til «noe» og «noe hellig». Håp synes også å være et ord som benyttes ofte som erstatning for tro:

Man har et håp da [...] selv om man har det dårlig så er man aldri helt alene. Du vet det er noen som er glad $i$ deg og alltid er noen som på en måte passer på.

Religion - organisert, dogmatisert

Rosén knytter denne modaliteten til en systematisert, institusjonalisert form for religiøsitet med en betoning av dogmer og leveregler som i mindre grad er formbar av den religiøse aktøren. Informantene har en betraktende og distansert 
holdning til religion som system. Flere har allikevel klare oppfatninger om at (andres) religion er knyttet til bestemte praksiser, ritualer, leveregler eller moral. Dette uttrykkes også ved at de nyanserer ved at en kan ha tilslutning til en religion i sterkere eller hyppigere grad, for eksempel som: «be hver dag», «tro sterkt», «følge hver eneste regel», «være veldig sikker», «være streng». Dette er en tro man forholder seg til, som mer eller mindre bestemmer hvordan en skal leve.

Når det kommer til egen religion, nyanseres bildet. Et typisk utsagn er «tro på det du vil», samtidig som flere er klar over at den sosiokulturelle konteksten spiller inn: «det spørs hva slags familie du kommer fra.» De som har en dogmatisk tilnærming til religion, synes samtidig å ha behov for å distansere seg fra det de oppfatter som uforståelige dogmer og fortellinger. En gutt fra Østlandet oppsummerer sitt syn, som flere av informantene i en viss grad slutter seg til:

Jeg er jo ikke spesielt kristen, men jeg vil ikke blande meg i hva folk tror på da. Men jeg tenker jo at det kan godt hende at det er en [Jesus] som har gått på jorda [...] bibelen, tror jeg ikke på. For eksempel ett brod fikk han til å bli til flere hundre folk liksom. $O g$ brennende plante, nei, jeg tror ikke på det. I hvert fall ikke for jeg fär sett det.

Flere tar opp kobling mellom religion og krig, vold og ekstremisme og reflekterer rundt hva som får «folk til å gå så langt for religionen sin». Enkelte konstaterer dette nærmest som et faktum: «Det er veldig mye krig i verden på grunn av religion». Religion forstås da som et system som forplikter, i motsetning til andre religioner eller ideologier. Enkelte tar opp det ondes problem og uttrykker at det er uforståelig at ikke Gud «bare fjerner all krig».

Enkelte av 14-åringene reflekterer også over hvordan ulike religiøse tradisjoner kan leve i fred side om side i vårt samfunn. En gutt fra Nord-Norge sammenligner den relativt homogene religiøse sammensetningen i sitt nærmiljø med det religiøse mangfoldet «nede i Oslo» og spør: «hvordan de klarer å komme så godt overens?», mens enkelte andre av informantene, særlig fra Midt-Norge og Østlandet, virker å ta dette for gitt.

\section{Praksis og ritualer}

Flere av våre informanter synes å støtte opp om praksiser som dåp og konfirmasjon, men uttrykker lite teologisk forståelse eller kunnskap om dem. Nattverd nevnes noen få ganger, for eksempel av en informant fra Midt-Norge som forteller at hun som har deltatt i det hun kaller «Guds blod»:

Jeg var ganske liten så jeg synes det smakte falt. Men, jeg, liksom, foler da at man har et bedre knyttepunkt til Gud da, på en måte. 
En annen har vært med på noe han kaller korstenning der man «tenner lys for dem man er glad i». Manglende teologisk forståelse for ritualet synes ikke å være et hinder for deltakelse og å finne det meningsfylt:

det hjelper ikke alltid å snakke om det, for det er ikke alltid man har ord til å uttrykke seg [...] Og da er det lettere [...] å tenne et lys.

Det uttrykkes kjennskap til tradisjoner, det som er sedvane i majoritetskulturen. (Se nedenfor om hvordan de unge forstår det å være kristen.)

En annen holdning som kommer frem, er at variasjon i religiøs praksis eller religioner imellom er en berikelse, og at det er viktig å respektere alle, uansett hva de tror på og praktiserer. Implisitt forstår ungdommene at religiøs praksis er knyttet til kulturell arv. En gutt fra Østlandet utrykker at å lære om andre religioner og kulturer er «bare morsomt det». Religioner som er fremmed for majoritetskulturen omtales imidlertid i mer eksotifiserende termer, og en blander i hop begreper og praksiser fra ulike religioner. En informant fra Østlandet forklarer at en religiøs jøde tror ikke på «en vanlig gud, du tror på Allah, ikke sant». Videre forklarer han at den (guden) bestemmer hvordan du skal leve og referer til «tonan eller kolan, husker ikke. [...] Du må ta på høyre sokk, høyre sko, venstre sokk, venstre sko og sånne ting, ikke sant.» (Se omtale av konfirmasjon som rite i de neste avsnitt.)

\section{Tradisjon}

Vi tolker vårt materiale slik at 14-åringene generelt har en delvis positiv holdning til folkekirkelige tradisjoner og praksiser. Lite kunnskap og erfaring med disse praksisene er ikke nødvendigvis til hinder for at de opplever dem relevante. Det er noe de har fått med seg i den konteksten de lever i. På den annen side fremstår «de andres» religiøse praksiser og tradisjoner i noen grad mer eksotisk, uforståelig og fremmed. (Her må vi presisere at vi ikke har informanter fra de mest flerreligiøse miljø i landet.)

Flere knytter kristelig konfirmasjon til tradisjon, det å tilhøre en kristen familie og at det er et «fint» og «koselig» ritual som betoner «samhold», «vennskap» og «familie». Ingen av 14-åringene bruker begrepet kultur-kristen, men flere uttrykker holdninger som mange vil tolke i denne kategorien. En jente fra Midt-Norge sier det slik:

Vår familie er heller ikke kristen, men vi går $i$ kirka da, på julaften, men det er bare fordi det er [...] en fin tradisjon som jeg foler holder familien sammen da [...] det trenger kanskje ikke å vaere religions-messig sett.

Det å befinne seg i rommet mellom voksenverden og barnets verden er et 
krevende arbeid. Flere av informantene uttrykker denne ambivalensen der utfordringen består i å finne kontinuitet mellom på den ene siden familiens religiøsitet og tradisjon og på den andre siden «finne seg selv» og forme en autonom og autentisk religiøsitet på egenhånd. Som en informant sier det om konfirmasjonsvalget: «Jeg synes det er viktig å kunne velge selv, men også fint å gå etter tradisjon etter familien.» En annen informant understreker det selvstendige valget og at det er foreldrenes oppgave å støtte opp om det individuelle valget:

... de legger valgene foran meg, men de sier aldri at jeg skal ta spesifikke valg [...] de snakker aldri om hva eller hvorfor [...] de er liksom villige til å kjøpe inn det som skal til, kjøre meg for eksempel til en moské på fredager og sånt.

De andre informantene i fokusgruppa uttrykker enighet $\mathrm{i}$ at foreldrene hadde støttet dem i det hypotetiske eksemplet ovenfor dersom de hadde valgt å bli muslimer. Også generelt finner vi en utbredt oppfatning om foreldres rolle primært som den støttende når det kommer til valg av konfirmasjon og religion. Vi kan snakke om en slags naiv individualisme, der 14-åringene fremsnakker det individuelle valget og samtidig er langt mer bundet og bastet til sitt opphav, når de faktisk foretar et valg. En av informantene lufter dilemmaet i familien der faren er muslim og ønsker borgerlig konfirmasjon for datteren mens moren ønsker kristelig. Hun heller mot kirkelig konfirmasjon, men avviser at det er på grunn av morens innflytelse: «Ja, det må æ bestemme sjøl da. Men æ har lyst til å ta kirkelig da.» Selv om det selvstendige valget står sterkt hos de fleste, ser vi samtidig en ambivalens og en viss anerkjennelse av familiens innflytelse som i denne utvekslingen mellom to informanter:

Info 4: Jeg vil jo velge det jeg vil velge. Jeg kommer jo ikke til å hore på familien hvis jeg har lyst til å feire[...] som buddhist, liksom, så ville jeg ikke hort på familien hvis de hadde villet at jeg skulle feiret kristelig. Fordi, det er jo mitt valg.

Forsker: $\mathrm{Mm}$.

Info 3: Jeg vil jo sikker hørt på dem, for dem har jo gått igjennom det for og hvis dem hadde tenkt på det og har sikkert vert gjennom det samme med foreldrene sine og dem skal ikke få bestemme hva jeg vil ha og dem har sagt at jeg skal få bestemme sjøl, å jeg tror nok at, eh, demmes meninger påvirker valget litt.

Feelgood-religion som en hjelpende praksis

Vi ser mange eksempler på at religion og religiøs tro forstås som støttende praksis og hjelp. Når informanter uttrykker seg om religion i positive vendinger, er 
det i stor grad noe som kan gi håp og psykologisk støtte til det enkelte individ (feelgood) og er primært emosjonelle og erfaringsbaserte og ikke kognitive. Slike uttalelser kunne gjerne vært assosiert med New Age, men vi finner ingen konkrete New Age-praksiser i vårt materiale, følgelig finner vi «feelgood- religion» som mer passende beskrivelse.

En informant forklarer for eksempel at tro er knyttet til solidaritet på den ene side og personlig velvære på den andre side: "[religion] dreier seg om hvordan behandle andre, og hvordan ha det godt med seg sjøl».

Andre understreker den subjektive side ved religiøsiteten slik:

- Må ikke nodvendigvis vare objektivt sant ... Så lenge det betyr noe for deg

- Religion gjøres på forskjellige måter og at alt er godkjent.

- Det er jo du sjøl som må ta å definere litt hva det er.

Som kontrast til det følelsesmessige står det teoretiske; når sannhet og objektivitet knyttes til religiøs tro, er det som en avkreftelse på at dette er viktig for troen og trosinnholdet. Det er en pragmatisk holdning som løftes opp som en viktigere verdi; «så lenge det betyr noe for deg». Tanker om meningen med livet er lite til stede i vårt materiale, mens uttrykket et godt liv kommer opp flere ganger i materialet vårt.

En støttende praksis og feelgood er noe flere fremhever i omtale av konfirmasjon. Dette knytter seg til hva en får i form av gaver, hvordan en kler seg / fremstiller seg, hvem en feirer sammen med, og det at en selv får være sentrum for en dag. Her er noen typiske uttalelser:

- Det er liksom en gang i livet og det er liksom noe du velger selv. Det er ditt liv du velger da.

- Det er ikke en dag sånn som vanlig. At man kan mimre litt om ting man har gjort som mindre [...] at man setter litt ekstra pris på ting den dagen.

- Gavene er viktig. Man må jo gi noe man foler den fortjener ...

- Jeg liker å vare sammen med familien min. Jeg har ganske mange i familien min som jeg ikke har sett på en stund og da blir det jo koselig å invitere de da.

- Viktigste er kanskje å samle hele slekta, de beste vennene dine og vare med alle de folka du trives best med

- Mamma og mormora mi hjelper meg å velge bunad, og dem spor meg kossen bunad jeg vil ha og så respektere dem det ... familien min stotter meg $i$ de valgene jeg tar

Vi leser deler av vårt materiale inn i den typologien som Inger Furseth (2019:299) foreslår, «good, bad and feelgood religion». 14-åringene uttrykker en skepsis mot religionsmodalitetens overbetoning på regler og dogmatikk (bad). Det er også 
nærliggende å tolke dette som samsvar med befolkningen generelt når majoriteten i Integreringsbarometerets siste undersøkelse (IMDI, 2020) uttrykker skepsis mot sterk religiøs tro. Informantene frakobler i noen grad trosinnhold og overbevisning fra det å identifisere seg som kristen eller å delta i kristen konfirmasjon, som kan forstås som vanlig (eller good) praksis, mens idealene som oftest betones, tolker vi altså som feelgood religion.

\section{Ambivalens til religion}

I denne kvalitative analysen får vi bekreftet at det er stor variasjon i forståelse av religion og religiøsitet blant de unge. Vi finner uttalelser som kan passe inn i alle de fem ulike modalitetene, slik Rosén har systematisert dem. Det er ikke et poeng i seg selv å plassere alle informantene og deres uttalelser inn i et slik fem-delt mønster, men det hjelper oss til å se variasjonen. Gjennomgående kan vi beskrive de unges oppfatninger som ambivalente og komplekse. Vi ser at de er i en livsfase der de står på terskelen mellom barndom, med sterk tilknytning til sin oppvekstfamilie, og til et mer selvstendig ungdomsliv der jevnaldrende og sosialt nettverk i $ø$ øende grad vil være referanser i livet. Ved å bruke abstrakte begreper som religion og religiøsitet vil det nødvendigvis skape ulike tanker, ut fra de referanser og den kunnskap en har. Slik kunne en også anlegge et utviklingspsykologisk perspektiv, og se det som alderstypisk at våre informanter er ambivalente. Samtidig tenker vi at disse unge også representerer noe kulturtypisk, som preger mennesker i vår tid og kulturkrets mer generelt. Furseth (2019) påpeker at religionskompleksitet i samfunnet innebærer at det foregår parallelle og motsetningsfylte prosesser som utfordrer etablerte religiøse kategorier. Noen uttrykker at det er vanskelig å velge og å følge én religion. Vi ser at våre informanter synes å ta for gitt at valg av religiøs identitet er individets selvstendige valg, og føyer seg slik inn i teorier om religiøs individualisering. Samtidig er mange klar over at de står i en tradisjon de også må forholde seg til når de velger. Når mange har behov for å nyansere eller distansere seg mot «helt» og «fullt» religiøs eller kristen, ser vi dette som et uttrykk for denne valgfriheten og ambivalens de unge står i. Vi ser dette når de blant annet sier:

- Jeg er ikke fullt kristen, men jeg er kristen

- Går ikke i kirka hver sendag, det er derfor vi ikke er helt kristne.

- Folger ikke akkurat alle regler, men tror på Bibelen

Dette fører oss over til å se nærmere på hvordan de unge forstår «å være kristen». 
Forståelse av fenomenet «å være kristen»

I fokusgruppeintervju fikk vi, som dokumentert ovenfor, varierte uttalelser om det å være kristen. Dette innebærer ikke bestemte felles kjennetegn. For noen var det viktig å skille mellom holdning/tro og atferd. En gjentagende differensiering var at man ikke behøvde å gå $\mathrm{i}$ kirken for å være kristen. Enkelte hadde også behov for å markere at det å vare kristen ikke var det samme som å være medlem i majoritetskirken. Hvilken status dåpen har for å forstå seg som religiøs eller kristen, varierer også blant informantene. Det kom blant annet til uttrykk i en dialog med to informanter at det å være døpt ikke er ensbetydende med å være kristen eller religiøs:

Forsker: Hvis man er dopt som barn ... betyr det da at man er religiøs?

Info 2: Det betyr ikke at du er religiøs siden à vare religiøs er noe du velger selv. Jeg er dopt $i$ kirken, det betyr jo at jeg er kristen [...] men jeg tror ikke på noe av det lissom [...]

Forsker: Er du enig $i$ en sånn forståelse? (henvender seg til en annen)

Info 4: Eh. Ja, men jeg er kristen, men jeg er ikke dopt. Mamma og pappa tenkte at jeg kunne bestemme selv ...

Differensieringen mellom det å være kristen og være religiøs, synes hos noen av informantene å være knyttet til at religiøs er et mer bevisst valg og/eller tilslutning til trosinnholdet, mens kristen synes mer å være knyttet til den formelle tilhørigheten til kirken. Det er da forståelig at det er en større andel som forstår seg som kristen enn som religiøs (se nedenfor). Her ser vi også visse geografiske variasjoner i hvordan disse begrepene oppfattes. Et eksempel på dette er bruk av begrepet «skriftlig kristen» som dukker opp i en fokusgruppe i Nord-Norge der informanten ser det i kontrast til å «tro på Gud». En mulig tolkning av dette begrepet kunne være at man tar troen og Bibelen bokstavelig eller skriftlig. Den mer nærliggende tolkningen, gitt konteksten, er at informanten forstår det som å være skriftlig innmeldt i kirken ved dåpen, det en kan omtale som nominell kristen.

Vi finner $i$ alle fokusgruppene at det å være religiøs og kristen omtales som en kan være dette i ulik grad. Det er ikke alltid klart om dette forstås som grad av overbevisning, praksis eller tilknytning til religiøst fellesskap. En rimelig tolkning når vi sammenlikner med resten av materialet, er at det særlig er grad av tilslutning til trosinnhold og religiøst aktivitetsnivå de unge plasserer inn i et spektrum. En av informantene forklarte at «[H]vis du er veldig kristen, så følger du hver eneste regel [...] og er liksom veldig sikker», mens andre i samme gruppe ga eksempler på grad av aktivitet ved å si at «mamma er ganske kristen», «faren min er litt religiøs», «jeg er[ikke] spesielt kristen». 
Informantene bruker ulike religiøse identitetsbegreper, men kristen forekommer langt hyppigere enn ikke kristen, jøde, muslim, buddhist, hinduist, livssynshumanist som kun brukes noen få ganger. Det er interessant, men ikke overraskende at det er kun de kristne identitetsbegrepene som sorteres i ulike grader og variasjoner i vårt materiale, som for eksempel litt kristen, veldig kristen, ikke kristen, katolikk, og frikirkelig. Dette kan nok tilskrives utgruppe-homogenitets-effekten (Myers, 2008, s325). Det betyr at majoriteten (de kristne) har en tendens til å anse de andre som mer ensartede, mens sin egen gruppe som en kjenner bedre, er mer differensiert og sammensatt. En annen nærliggende tolkning er at informantene søker å nyansere de begrepene de selv står nærmest, for å unngå å bli innlemmet i stereotype forestillinger eller potensielt stigmatiserte grupper. De utøver det Vassenden og Andersson (2011) omtaler som religiøs informasjons-kontroll.

På grunnlag av de varierte svarene i fokusgruppene fant vi det relevant i spørreundersøkelsen å undersøke mer hvordan de unge forstår det å være kristen, og hvilken praksis som forbindes med dette, se figur 1 .

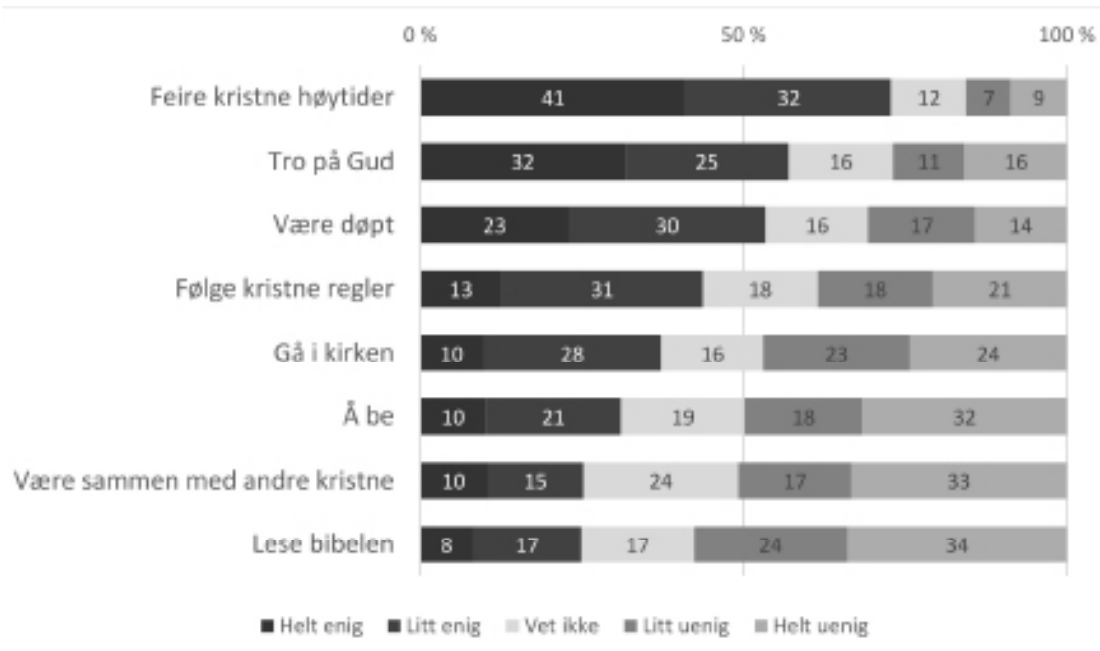

Fig. 1: Spørsmålet «I hvilken grad er du enig eller uenig i hva som er viktig ved å vere kristen?» er sortert etter synkende gjennomsnittsverdi. Prosentverdier for hver kategori. Totalt $100 \%$ for hvert spørsmål. N=309, inkludert «vet ikke».

Vi ser her at de fleste respondentene forbinder det å være kristen med høytidene. Det virker naturlig da de fleste markerer disse, uavhengig av om de kommer fra såkalte kristne hjem. De minst relevante karakteristikkene for 14-åringene er det å lese bibelen, å være sammen med andre kristne, og å be. Mange er også uenige $i$ at det å gå i kirken er kjennetegn på å være kristen.

Når karakteristikkene i Fig. 1 analyseres mot kjønn, landsdel og valg av konfirmasjonstype, er det ingen forskjeller mellom kjønnene og få forskjeller mellom 
ungdommer fra ulike landsdeler. Derimot er det interessant at de som planlegger et annet konfirmasjonsopplegg enn humanistisk eller i DnK, gjennomgående velger karakteristikker knyttet til en praksis ved det å være kristen, slik som å lese i bibelen, be og være sammen med andre kristne. Vi forstår dette slik at flere i kategorien «annet» tilhører mindre trossamfunn hvor ulike uttrykk for tro er viktige identitetsmarkører.

\section{Religiøs selvforståelse - og valg av konfirmasjon}

Vi har sett i fokusgruppene at de unge har behov for å nyansere når de omtaler seg selv som kristen, religiøs eller troende. De graderer og har behov for å ta avstand fra visse praksiser og holdninger. Når vi i spørreskjema skulle få standardiserte svar, fant vi det derfor mest riktig å gi dem en gradert skala. De ble bedt om å plassere seg på en skala fra «Helt enig» til «Helt uenig» for påstandene: «Jeg er kristen», «Jeg er religiøs» og «Jeg tror på Gud» (Fig. 2).

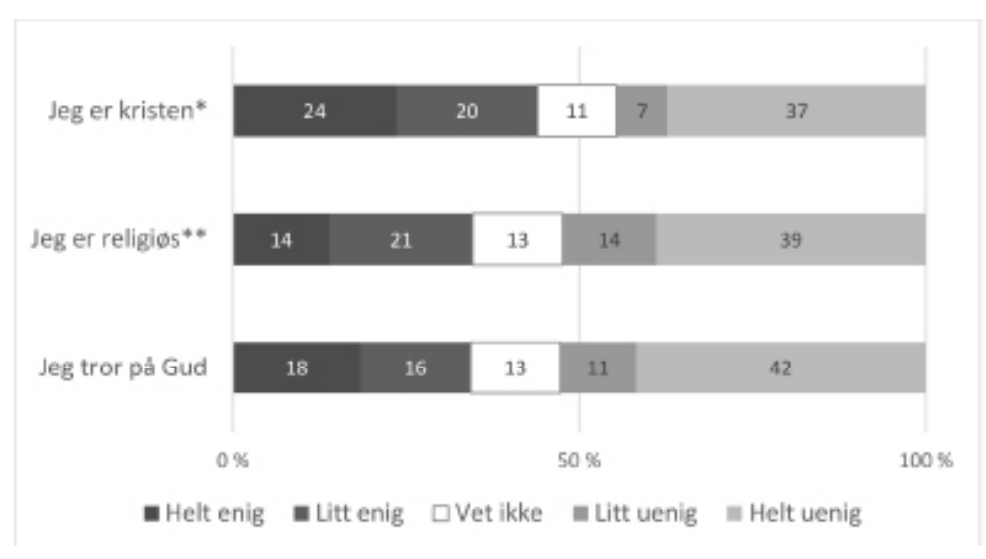

Fig. 2: «Hvilke utsagn passer best for deg?». ** Signifikant forskjellig mellom kjønn.

Prosent-verdier for hver kategori, totalt $100 \%$ for hvert spørsmål. $N=309$ for hvert spørsmål

Rundt $40 \%$ svarer at de er «Helt uenig» i de tre påstandene om egen tro (Fig. 2). Litt over $10 \%$ svarer «Vet ikke» på de tre spørsmålene om egen tro. Det er ca. 1/3 som er helt eller litt enig $i$ at «Jeg er religiøs» eller «Jeg tror på Gud», mens det er en litt større andel som sier «Jeg er kristen». Jentene opplever seg selv som mer religiøse enn guttene og de som karakteriserer seg som «annet» kjønn.

Når de unge svarer på disse spørsmålene, vet vi ut fra fokusgruppene at de legger noe ulik forståelse i de aktuelle begrepene. Ungdommene har også sitt eget språk. Denne variasjonen er noe en må ta høyde for når en skal forstå deres svar på standardiserte spørsmål.

Samtidig som det er variasjon i forståelse av ulike begreper, er det sannsynlig en viss endring over tid. Det er overraskende stor forskjell på noen av svarene i 
forhold til tilsvarende undersøkelser på 1990-tallet (Birkedal 1996 og 2001). Det er en større andel i herværende undersøkelse som forstår seg som helt eller litt enig $i$ at de er «kristen», oppgir at de er religiøse, eller har en tro på Gud. Vi kan spørre oss om det har skjedd en mentalitetsendring på dette i løpet av disse 25 årene, der dagens unge har mindre behov for å markere distanse til det etablerte / foreldre, enn det som var tilfelle på 1990-tallet, eller om det er begrepsinnholdet som endres? Vi merker oss også at det er flere unge i 2019 som omtaler seg som kristen, enn som religiøs eller troende. Ut fra vår analyse forstår vi dette slik at det å være kristen for mange innebærer en tilhørighet til en tradisjon/kultur, mens det å være religiøs eller troende i større grad innebærer en personlig holdning. Det er samtidig verd å merke seg at det er en stor andel som er «helt uenig» (ca. 2/5) eller «vet ikke» når det gjelder å forstå seg som enten kristen, gudstroende eller religiøs. Vi tolker det som at mange passer inn i kategorien «nones».

Vi har sett på sammenhengen mellom egenforståelse som kristen / religiøs / tro på Gud, og valg av type konfirmasjon. ${ }^{7}$ (Fig. 3 a, b og c). Det er klare tendenser i hvilken trosholdning majoriteten i de ulike grupper har, men det er slett ikke entydige eller ensartede grupper.

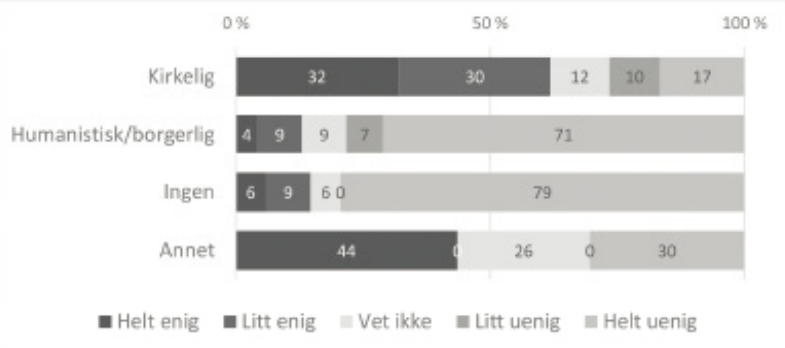

Fig. 3 a: Spørsmålet "Jeg er kristen" fordelt over type konfirmasjon. Prosent-verdier for hver kategori $i$ hvert spørsmål. $N=309$.

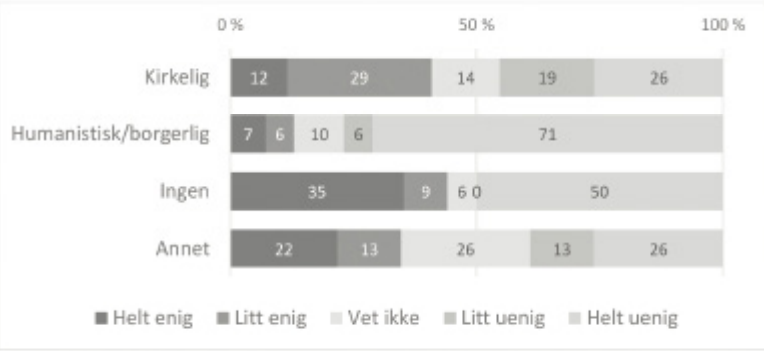

Fig. 3 b: Spørsmålet "Jeg er religiøs" fordelt over type konfirmasjon Prosent-verdier for hver kategori i hvert spørsmål. $N=309$.

7 For mer utfyllende analyse og drøfting av de unges valg av konfirmasjon vises til Birkedal og Grimsby 2019. 


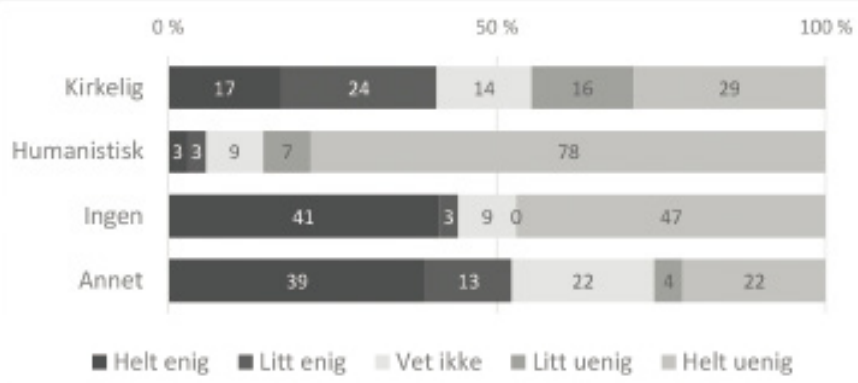

Fig. 3 c: Spersmålet "Jeg tror på Gud" fordelt over type konfirmasjon de unge vil velge. Prosent-verdier for hver kategori i hvert spersmål. $N=309$.

Generelt kan vi se at det er en signifikant forskjell mellom hvordan ungdommene tenker om egen tro, ut fra hvilken type konfirmasjon de planlegger (Fig. 3 a, b og c). Men det er slett ikke noen homogene grupper ut fra disse tre variablene, «Jeg er kristen / religiøs / tror på Gud».

Blant dem som planlegger kirkelig konfirmasjon, svarer over $50 \%$ at de enten er helt eller litt enig $\mathrm{i}$ at de er kristne, mens ca. $1 / 4$ er litt eller helt uenig $\mathrm{i}$ at de er kristne. Det er litt under halvparten i denne gruppen som velger kirkelig som sier de er helt eller litt enig $i$ at de er religiøs eller tror på Gud, og ca. like mange som er litt eller helt uenig i dette. I fokusgruppene ser vi at denne bredden avspeiles i en variasjon i begrunnelse for valg av kirkelig konfirmasjon. Noen har bestemt seg ut fra at de er overbevist kristne. Noen sier de følger tradisjonen i familie. Mange i denne gruppen gir også uttrykk for en religiøs ambivalens, som en sier: «Jeg velger kirkelig fordi jeg er kristen, tror jeg i hvert fall». Det å være døpt er ikke en selvfølgelig begrunnelse eller argument for 14-åringer når de velger kirkelig konfirmasjon.

Majoriteten av ungdommene som planlegger humanistisk/borgerlig konfirmasjon har et mer klart standpunkt i spørsmålene om egen tro, da 70-75\% er helt uenig $i$ at de er kristne, religiøse og tror på Gud. Samtidig ser vi at det er en viss andel (ca. $10 \%$ ) som sier de er kristne, religiøse eller tror på Gud. I fokusgruppene er det også i denne gruppen lite argumentasjon eller begrunnelse for deres valg, med hensyn til tro og religion. Det er en som uttrykker sin ambivalens ved å si at han/ hun velger borgerlig «fordi jeg ikke tror på Gud», men legger samtidig til «selv om jeg er kristen da.»

Blant dem som planlegger "Annet» konfirmasjonsopplegg er det størst andel som helt sikkert er kristne, religiøse og tror på Gud. Mange av disse ungdommene tilhører trolig kristne trossamfunn utenfor Den norske kirke, slik vi fant eksempler på i fokusgruppene. 
Mer enn $40 \%$ av dem som sier Ingen / ikke skal konfirmere seg svarer at de både er religiøse og tror på Gud, mens rundt $10 \%$ sier de er helt eller litt enige i å forstå seg som kristne. At det er vesentlig mindre andel kristne, sett i forhold til religiøse og troende, kan være et signal om at de opplever liten tilknytning til kristent trossamfunn på sitt sted. I fokusgruppene er det noen som sier de har tilknytning til en tydelig tradisjon som f.eks. katolsk kirke, mens andre sier de ikke ønsker «noe styr», og tenker da blant annet på hvem som eventuelt skal inviteres i selskap. Andre igjen sier de vil ha bare familieselskap i stedet for offentlig ritual, for å få en markering.

I fokusgruppene ser vi at blant de usikre, de som ikke har bestemt seg for konfirmasjonstype, er det vanligvis også en usikker og lite reflektert forståelse av religion. De uttrykker som «nones» at religion generelt og personlig vedkommer dem i liten grad. Det er også gjennomgående at disse ikke viser til foreldre med klar preferanse til å være religiøs eller kristen.

\section{Avsluttende Drøfting}

Hva skal vi svare på de tre forskningsspørsmålene vi stilte innledningsvis?

For det første: Hvilke implisitte forståelser av religion viser 14-åringene når de snakker om religion og religiøsitet? Vi ser en stor variasjon i forståelse av religion og religiøsitet. Samtidig er ambivalens eller usikkerhet om hva det er å være religiøs, utbredt. Vi ser noen som knytter det religiøse primært til en holdning / det emosjonelle. Noen har en mer kognitiv tilnærming, mens andre har en sosial tilnærming der en legger vekt på en bestemt praksis eller det som er tradisjon. Religion som er fremmed / langt borte, kan omtales som konfliktfylt og eksotisk. Den religion og religiøse praksis en selv kjenner, omtales i hovedsak i positive vendinger, noe som gir håp og psykologisk støtte, en «feelgood-religion». Vi ser en variasjon i forståelse av det å være kristen. Her er det noen som nyanserer mellom det formelle (som å være døpt og medlem i et trossamfunn) og det kognitive (hva en tenker) og emosjonelle (hva en tror på). Det er de som forstår seg som kristne, som synes å mene at det å være kristen innebærer en spesifikk praksis (Fig 1). Vi tenker det er sannsynlig at personenes oppfatning av seg selv og hvordan en uttrykker seg om religiøsitet, er farget av egen tradisjon og erfaringer. 13-14åringer preges av den kontekst en er $\mathrm{i}$, og vil endre seg over tid på grunnlag av nye erfaringer og innsikt. Vi tenker at dette kan forstås som en diskurs som er under påvirkning av eksterne faktorer, en pågående prosess og forhandling i retning av en mer tydelig tolkning av begreper og meninger.

For det andre: Hvilke religiøse selvforståelser har 14-åringer i dagens Norge, og hvordan henger dette sammen med valg av konfirmasjon? Vi finner en stor variasjon av religiøs selvforståelse, og det er ikke for alle en åpenbar sammenheng mellom religiøs selvforståelse og valg av konfirmasjon. Blant de 14-åringer som tenker å 
velge kirkelig konfirmasjon, sier majoriteten at de er litt eller helt kristne (Fig 2). De fleste som velger borgerlig konfirmasjon, sier de verken er religiøse, kristne eller tror på Gud. Samtidig ser vi at det også finnes de som er både selvbevisste kristne og tror på Gud, som velger borgerlig, og tilsvarende en relativt stor andel av de som velger kirkelig konfirmasjon, som sier de ikke er kristne, religiøse eller troende. Mange viser stor grad av ambivalens, men liten grad av opposisjon mot det religiøse. Dette samsvarer med det som også er gjort av tidligere forskning på kirkelige konfirmanter. Høeg omtaler en gruppe blant kirkelige konfirmanter som «borgerlig / HEF-orienterte» (Høeg 2010:178-179). Denne kompleksiteten og ambivalensen kan også forstås med et noe mer positivt fortegn gjennom det Helge Ridderstrøm (2005) kaller ungdommens kombinasjonskunst, evnen til å omskape andres ytringer og begreper, til kreativt å dekonstruere og rekonstruere gammelt materiale til en ny «religious bricolage».

Hvordan skal vi så forstå at det ikke er mer samsvar mellom religiøs selvforståelse og valg av konfirmasjon? Ved at vi stiller et slikt spørsmål, anlegger vi en analytisk, kognitiv tilnærming. Vi forutsetter implisitt at det bør være en sammenheng mellom egenforståelse og de verdier og rammer som er i de ulike konfirmantopplegg. Vårt materiale bekrefter at det ikke bare er en slik kognitiv logikk som gjelder for de unge. Kanskje det vil skape større forståelse å se på sammenhengen mellom egenforståelse og valg av konfirmasjon ut fra en sosial logikk eller en emosjonell logikk. Da vil den diskrepansen vi ser i statistikken, ikke bli så merkelig. Individets relasjon til tradisjon og familie, og ikke minst venner, blir da mer relevant for å forstå deres valg. I vårt materiale ser vi en stor lojalitet mot familie og tradisjon de unge er født inn i. Denne lojalitet kan tyde på at 14-åringene lever mer i sin «barndom» enn $i$ en ungdomskultur der jevnaldrende har størst betydning og de unge har behov for å markere selvstendighet i forhold til sine foreldre. For foreldregenerasjonen handlet nok ungdomstiden og dermed overgangsrite i større grad om å innta sin plass, mens nå handler det i større grad om å finne sin plass. Samtidig som 14-åringene velger relativt tradisjonelt, opplever de at det forventes av dem at de skal velge selv. De setter det selvstendige valget høyt uten at de nødvendigvis aner familiens og andres innflytelse, og uttrykker således en naiv individualisme. Ole Jacob Madsen tegner et bilde av «generasjon prestasjon» med utallige valgmuligheter, men også ansvaret for å mestre livet på ulike arenaer, og spør om kostnaden ved individuell frihet og privilegier er verdt det i form av økte psykiske plager og stress. (Madsen, 2018:82). Valg av konfirmasjon kan bli nok en mestringsarena for noen, som fordrer personlig prestasjon og selv-presentasjon. Valget kan for mange synes å være en relativt lett oppgave, mens det for noen kan oppleves som «religionsmestring» og dermed nok en arena der man skal presentere seg riktig og prestere godt. Valg av konfirmasjon forstått som valg av religion, særlig institusjonell eller dogmatisk tilhørighet, 
kan oppleves som et valg man ikke har forutsetninger for å ta. Ut fra en kognitiv logikk kan det forstås som mangel av nok kunnskap, mens det på den annen side kan være mangelen av en sterk familietradisjon som legger premissene. Ut fra en sosial logikk kan vi også ane en form for kategoriseringsvegring. Det er en side av FOMO (fear of missing out) (Barry \& Wong 2020), der man vegrer seg for å bli bundet til én religiøs kategori man har ambivalens mot. En side av dette er at man søker å kontrollere hvilken type og mengde informasjon om egen religiøsitet som kommuniseres. For enkelte majoritetsungdommer blir norsk etnisitet en markør som skjuler religiøs identitet, mens ikke-hvite etnisiteter avdekker religiøsitet (Vassenden og Andersson, 2011). For enkelte kan norsk etnisitet tyde på en sekulær identitet, også forstått som en mer nøytral posisjon (Gilsvik, 2018), noe som betyr at valg av konfirmasjon navigeres og legitimeres i variasjon med informantens etnisitet og sosiale kontekst.

For det tredje: Hvilken implisitt forståelse av konfirmasjonen har de unge?

Ut fra det som er sagt ovenfor, er det nærliggende å omtale konfirmasjonen som en «familierite». Samtidig som det skjer en seremoni i et tros-/livssynssamfunn, er det samvær med familie og gaver fra familie til de unge som er sentrale elementer. Det fenomenet at noen velger «ingen konfirmasjon», men har «bare» familieselskap eller en spesiell gave til den unge, underbygger at «familieriten» står sterkt. $^{8}$

Tradisjonelt har det vært vanlig å se på konfirmasjonen som en overgang fra barndom til voksenlivet, der det markerer endring $i$ ansvar, status, fra skole til arbeid. Da er det vanlig å bruke begreper som «overgangsrite», «rites de passage» eller «liminalitet» (Gennep 1999 / Danbolt og Stifoss-Hanssen 2014:205). Men gir det i vår kontekst god mening å snakke om konfirmasjon som en overgang? Overgang fra hva til hva? De unge som blir konfirmert, er vanligvis midt $\mathrm{i}$ ungdomsskolen. Riten markerer ikke avslutning av obligatorisk skole, slik det gjorde for noen tiår siden. Det er ikke starten på en livsfase med økonomisk ansvar og inngang i de voksnes yrkesliv.

Når det gjelder de unges forhold til religion, kan begrepene «overgang» og «terskel» gi en viss mening for konfirmasjonen. Vårt materiale viser at 14-åringene er «terskelmennesker» (Turner 1997) $i$ den betydning at de er i grenseområdet mellom en fortid som er i ferd med å avsluttes (barndom) og en fremtid som nærmer seg (selvstendig ungdomstid). De befinner seg også i en endringsprosess eller $i$ et religiøst identitetsarbeid. De har en ambivalens som er både knyttet til manglende oversikt og kunnskap, tilhørighet til familie og tradisjon og samtidig med et individualistisk ideal av autonomi og autentisitet, der de selv skal mestre. De lever til en viss grad i barndommen, som del av en gitt familie, og står på

8 Se Grimsby og Birkedal 2020 for nærmere analyse og drøfting av konfirmasjon som familierite, samt ulike motiver for valg av kirkelig konfirmasjon og utfordringer dette gir kirken. 
terskelen til et åpent landskap med mange muligheter og valg. Konfirmasjonen sammenfaller også med den religiøse myndighetsalder, 15 år, der en selv kan velge seg ut og inn av trossamfunn og stemme ved kirkelig valg (Den norske kirke). Ellers må vi konstatere at unge flest merker lite til en overgang ved konfirmasjonen, med et tydelig før og etter. Det er ingen klare grenser som blir overskredet, eller skille mellom de som har / ikke har blitt konfirmert. Når det gjelder religiøs endring eller identitetsarbeid, synes også konfirmasjonstiden i liten grad å være konkluderende. Høeg har i sin forskning på kirkelig konfirmasjon funnet at omtrent like mange konfirmanter oppgir at de tror på Gud ved avsluttet konfirmasjon som da de begynte (Høeg 2017:27).

Vi ser at informantene har ulike og blandede tilnærminger til valg av konfirmasjon, der deres religiøse holdning er én av flere. For å forstå dagens unge sin oppfatning av konfirmasjon som rite, må vi kanskje se riten ut fra et sosialt og emosjonelt perspektiv. Det er selve konfirmasjonen (riten) 14-åringene i hovedsak tenker på når de omtaler konfirmasjon, ikke den undervisningen som foregår $\mathrm{i}$ tiden før. Det dreier seg i stor grad om hvem som skal inviteres til selskap, gaver og det en skal ha på seg (f.eks. bunad). Som religiøs praksis fremstår konfirmasjonen som «feelgood»-religion. I et slikt perspektiv blir konfirmasjonen en rite for bekreftelse og anerkjennelse, der en får være «konge for en dag». Det er handlingen i seg selv som er i fokus. En slik opplevelse av konfirmasjonen støtter også opp om de funn Jone Salomonsen fant for over ti år siden (Salomonsen 2007: 169). På den måten er det nærliggende å betegne en slik konfirmasjonsforståelse som «ritual performance». (Driver 1998, Danbolt og Stifoss-Hanssen 2014:211-12). Det er en opptreden og fremstilling der individet blir sett og bekreftet av betydningsfulle andre, familie og venner, og for dem som velger kirkelig, inkluderer dette også Gud. Slik kan konfirmasjonen fremstå som en motvekt til den kulturen og de krav de unge opplever ellers i samfunnet, slik det omtales blant annet $i$ «Generasjon prestasjon» (Madsen 2018). En stor andel av 14-åringene ser frem til en slik rite, og kanskje de også ser ritens mulige «resiliensfaktor»? Kan konfirmasjon være en hjelp til livsmestring og gi motstandskraft i møte med prestasjonskulturens psykiske plager og stress? I stedet for å oppleve individuelle krav, religiøs mestring, riktig bekjennelse og dogmer, fremstår en slik rite med et potensial til å bekrefte sin tilhørighet til et ordnet hele, sin familie og for noen en større enhet, og gi livet en følelse av mening. En slik forståelse finner støtte i «sosial identitetsteori» (Hogg 2006. Danbolt og Stifoss-Hanssen 2014:213-214). Menneskets behov for sosial tilhørighet kan være en positiv drivkraft for å opprettholde konfirmasjonen som folkelig rite. 


\section{Konklusjon}

Målet med denne artikkelen er å søke ny innsikt i 14-åringers forståelse av religion og religiøs selvforståelse og deres valg av konfirmasjon, i forkant av valget, og dermed også deres oppfatning av konfirmasjon som rite før den gjennomføres. Noen funn om religiøs variasjon og ambivalens bekreftes i stor grad av tidligere forskning blant konfirmanter i folkekirken.

Hos 14-åringene ser vi en variasjon i ulike former for religiøse modaliteter eller hvilke sider ved religionen som vektlegges, og samtidig stor variasjon i religiøs selvforståelse. Dette er ikke overraskende i et bredt utvalg fra årskullet. Det som kan være mer overraskende, er at hele bredden av variasjon er representert i de ulike typer konfirmasjon. 14-åringene er i stor grad tradisjonelle, i den forstand at de forholder seg til den religiøse tradisjon (eller mangel på slik tradisjon) de er vokst inn i. Konfirmasjon fremstår i stor grad som en familierite, samtidig som de unge markerer at de har et fritt, selvstendig valg. Familietradisjon og kollektiv identitet kan slik overstyre den individuelle religiøse selvforståelse. Det som synes å være fremtredende for de unge som enda ikke har valgt konfirmasjon, er en oppfatning av konfirmasjonen som en arena der en iscenesetter sitt eget liv og blir bekreftet. Det er en arena for å bli sett og få anerkjennelse av signifikante andre, uansett hvilken form for konfirmasjon en velger.

\section{LitTERATUR}

Barry, C. T., \& Wong, M. Y. 2020. «Fear of missing out (FOMO): A generational phenomenon or an individual difference?» Journal of Social and Personal Relationships, 37(12), 2952-2966. https://doi.org/10.1177/0265407520945394

Birkedal, Erling. 1996. «Gudstro i tidlig ungdomsalder. En empirisk undersøkelse i det sentrale østlandsområdet.» I: Tidsskrift for Kirke, Religion og Samfunn. Hefte nr.2. Årgang 9, s.143-154.

Birkedal, Erling. 2001.»Noen ganger tror jeg på Gud, men ...» En undersøkelse av gudstro og erfaring med religiøs praksis i tidlig ungdomsalder. KIFO Perspektiv nr. 8. Tapir Akademiske Forlag. Trondheim.

Birkedal, Erling og Grimsby, Lars Kåre. (2019). 14-åringer og konfirmasjon. Ungdomsundersøkelse 2019. MF Rapport 2:2019. MF vitenskapelig høyskole.

Danbolt, Lars Johan og Stifoss-Hanssen, Hans 2014: «Å skape mening gjennom symbolske handlinger.» I Danbolt (red). Religionspsykologi. Gyldendal Akademisk, Oslo 2014. Gyldendal Norsk Forlag.

Davie, Grace. 2015. Religion in Britain: A Persistent Paradox. London: John Wiley \& Sons.

Driver Tom. 1998. Liberating Rites. Understanding the Transformation Power of Ritual. Boulder: Westview Press. 
Furseth, Inger, Kühle, L., Lundby, K., \& Lövheim, M. 2019. «Religious Complexity in Nordic Public Spheres.» Nordic Journal of Religion and Society, 32(01), 71-90.

Gennep, Arnold Van. 1999. Rites de passage. Overgangsriter. Oslo: Pax.

Gilsvik, Espen. 2018: Managing tension, navigating conflict. Exploring possibilities and limitations of religious beliefs and practices in the everyday life experiences among high school students in Oslo. Masteravhandling: MF vitenskapelig høyskole.

Grimsby, Lars Kåre og Birkedal, Erling 2020. «Unges tanker om konfirmasjon. En studie blant 14-åringer forut for deres valg av ungdomsrite.» Tidsskrift for praktisk teologi. Årg. $37 \mathrm{Nr} 2 / 2020$, s. 22-38

Hogg, M.A. 2006. Social Identity Theory. I Burke, P.J. (red.) Contemporary Social Psycological Theories (s.111-136). Stanford: Stanford University Press.

Holmqvist, Morten (red.) 2007. Jeg tror jeg er lykkelig ... Ung tro og hverdag. Oslo: Kloster forlag.

Høeg, Ida Marie 2010. ««Friheten til å tenke og mene hva du vil er en menneskerett» Humanistisk eller kristen konfirmasjon?» I Krupka, Bernd og Reite, Ingrid (red.). 2010. Mellom pietisme og pluralitet. Konfirmasjonsarbeid i fire nordiske land. Oslo: IKO-Forlaget.

Høeg, Ida Marie og Krupka, Bernd. 2015. «Confirmation Work in Norway.» I Schweitzer et. al. (red.). Youth, Religion and Confirmation Work in Europe. The Second Study. Gütersloh: Gütersloher Verlagshaus. s. 234-244

Høeg, Ida Marie. 2017. Religion og ungdom. Oslo: Universitetsforlaget.

Krupka, Bernd og Reite, Ingrid (red.). 2010. Mellom pietisme og pluralitet. Konfirmasjonsarbeid i fire nordiske land. Oslo: IKO-Forlaget.

IMDi. 2020. Integreringsbarometeret 2020. Rapport. Oslo: Integrerings- og mangfoldsdirektoratet (IMDi)

Madsen, Ole Jacob. 2018. Generasjon prestasjon. Hva er det som feiler oss? Oslo: Universitetsforlaget.

Myers, David G. 2008. Social Psychology. New York: McGraw-Hill

Putnam, R.D, Campbell, D.E. 2010. American Grace. How Religion Divides and Unites Us. New York: Simon \& Schuster.

Rosén, Ina. 2009. I'm a Believer - But I'll Be Damned if I'm Religious. Belief and Religion in the Greater Copenhagen Area. A Focus Group Study. Lund: Centrum för teologi och religionsvetenskap, Lunds universitet.

Salomonsen, 2003. «Riter som utfordring til konfirmasjon.» I Synnøve Heggem og Espen Dahl (red). Dåp - Konfirmasjon - Kateketisk Praksis. Et riteperspektiv på sosialisering. Oslo: Det praktisk-teologiske seminar

Salomonsen, Jone. 2007. «Initiation to Adulthood. The Challenge of Modernity, the Paradox of Ritual, and the Gifts of Confirmation in Norwegian Context.» I Trygve Wyller og The Given child. The religions' contribution to children's 
citizenship. Göttingen: Vandenhoeck \& Ruprecht.

Schweitzer, Friedrich, Wolfgang Il og Henrik Simojoki (red.). 2010. Confirmation Work in Europe. Empirical Results, Experiences and Challenges. A Comparative Study in Seven Contries. Gütersloh: Gütersloher Verlagshaus.

Schweitzer, Friedrich, Kati Niemelä, Thomas Schlag, Henrik Simojoki (red.). 2015. Youth, Religion and Confirmation Work in Europe. The Second Study. Gütersloh: Gütersloher Verlagshaus.

Stolz, Jörg (red.) Könemann, Judith, Schneuwly Purdie, Mallory, Englberger, Thomas, Krüggeler, Michael. 2016. (Un)Believing in Modern Society. Religion, Spirituality, and Religious-Secular Competition. Milton Park, Abingdon: Routledge Storvoll, Sindre. 2007. Kristenfiendtlighet i pressen? Norske avisers dekning av kristendom og islam. Masteravhandling: $\mathrm{UiO}$

Turner V.W. 1997. The Ritual Process. Structure and antistructure. Piscataway. NJ: Aldrine Transaction.

Vassenden, Anders og Andersson, Mette. 2011. Whiteness, non-whiteness and 'faith information control'. Religion among young people in Grønland, Oslo, I Ethnic and Racial Studies, 2011; Vol. 34, No. 4. (574-593)

Vetlesen, Arne Johan, Wiig, Rasmus. 2018. Hva skal vi svare våre barn? Oslo: Dreyers forlag. 